\title{
NRC Plan for Cleanup Operations at Three Mile Island Unit 2
}

Manuscript Cumpleted: March 1984

Date Published: March 1984

TMI Prograın Office

Office of Nuclear Reactor Regulation

U.S. Nuclear Regulatory Commission

Washington, D.C. 20555

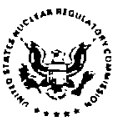


(20.6.

\section{Availability of Reference Materials Cited in NRC Publinations}

Most document cited in NRC publications will bo avallable from one of the following sources:

1. The NRC Public Dosument Room,.1717 H Stret, N.W. Washington, DC 20555

2. The NRC/GPO Sales Program, U.S. Nuclear Regulatory Commitsion, Washington, DC 20555

3. The National Technical Information Service, Springfield, VA 22161

Although the listing that follows sepresents the majority of documents cited in NRC publications, it is mot in tended to be exhaustive.

Referenced docurrents available for inspection and copying for a fee from the NRC Public Document Room include NRC correspondence and intemal NKC memoranda; NRC Office of Inspection and Enforcement bulletins, circulars, information notices, inspection and investigation notices; Licensee Event Rcports; vendor reports and cortespondence; Commission papers; and applicant and licensee documents znd correspondence.

The following documents in the NUREG series are available for purchase from the NRC/GPO Sales Program: formal NRC staff and contractor reporț, NRC-sponsored conference proceedings, and NRC booklets and brochures. Also available are Regulatory Guides, NfiC regulations in the Code of Federal Regulations, and Nuclear Regulatory Commission lssuances.

Documents available from the National Technical Information Service include NUREG series reports and technical reports srepared by other federal agencies and repors prepared by the Atomic Energy Commission, forerunner agency to the Nuclear Regulatory Commission.

Documents available from public ariv special technical libraries include all open literature items, such as books, joumal and periodical articles, and transactions. Federal Register notices, federal and state législation, and congressional report's can usualiy be obtained from these libraries.

Documents such as theses, dissertations, foreign reports and transtations, and non-NAC conference proceedings are available for purchase from the organization sponsoring the publication cited.

Single copies of NRC draft reports are available free upon written request to the Division of Technical Information and Document Control, U.S. Nuclear Regulatory Commission, Washington, DC. 20555.

Copies of industry codes and standards used in a substantive manner in the NRC regulatory process are maintsined at the NRC Library, 7920 Norfolk Avenue. Bethesda, Maryland, and are available there for reference use by the public. Codes and standards are usually copyrighted and may be purchased from the originating organization or, if they are American National Standards, from the Amorican National Standards institute, 1430 Broadway. New York, NY icoia.

GPO Printed copy price: $13,-1,5$ 


\section{ABSTPACT}

This report upates a plan that defines $N R C^{\prime} s$ role in cleanup uperations at Three Mile Isiand Unit 2 (TMI-2) and outlines NRC's ren::latory responsibilities in fulfilling this role. These respansibilities include reviewing a.ld approving General Public Utilities Nuclear Corporation (the licensee) proposals for cleanup actions, overseeing the licensee's implementation of approved activities, coordinating with other Federal and state governmental agencies on their activities in the cleanup, and inforning local officia?s and the public about the status of the cleanup.

Since the initial issuance of this NRC Plan in July 1980, this office has issued the Final NRC Programmatic Environmental Impact staterlent (PEIS) related to the entire THI-2 cleanup and a draft Supplement to the DE is related to occupational radiation exposure. Additionally, a number of developments have occurred which will have an impact on the course of cleanup operations. This revision pravides a discussion of these developments, specifically in the areas of the functional role of the NRC in cleanup operations, the cieanup schedule, and the current status of the clearup. The plan al so discusses NRC's perceived role in future cleanup activities. Because of major uncertainties in the funding of the cleanup, portions of this plan, including the estimated schedule, are likely to require further changes as availability of funding and other faccors offect the face of the cleanup. 
1. THE PURPOSE AND SCOPE

2. THE NRC OBJECTIVES IN TMI-2 CLEANUP OPERATIONS

3. NRC FUNCTIONS

3.1 Support Functions

3.2 Coordination Functions

3.3 Infomation functions

$3-4$

3.4 Ndvira and Reconiaendation Functions

$3+4$

3.5 Regulatory Overs ight 5unctions

4. NRC REVIEW AND DECISION-MAKING PROCEOURE

4.1 Proposals From The Licensee 4-1

4.2 The NRC Review Process 4-1

5. THE MASTER SCHEDULE OF MAJOR CLEANUP ACTIONS 5-1

6. Status OF CLEANUP RELated activities 6-1

6.1 Completed Activities 6-1

6.2 Ongoing Cleanup Activities 6-3

6.3 Future Activities Requiring HRC Review and Approval 6-5

7. LICENSEE IMPLEMENTATION OF ACTIONS $7-1$

7.1 NRC ACtions 7-1

7.2 Other Agency Actions $7-1$

2. REFERENCES 8-1

APPENDIX A Menarandum of Understanding, NRC-DOE, Concerning The Removal and Disposition of Sol id Muclear Wastes From Cleanup of TMI $-2 \ldots \ldots \ldots \ldots \ldots \ldots \ldots \ldots \ldots$ 


\section{ABRREVIATIONS}

AFHS

ALARA

CEQ

CFR

CY

DOE

DOT

EPA

EP ICOR-I I

GPUNC

IE

NMSS

MOU

NEPA

IIRC

NRR

OELD

PEIS

RES

RCS

RPV

RPVH

SDS

TAAG

TMIPO

TMI - 2
Auxiliary and Fuel Handiing Building

As Low as Reasonably Achievable

President's Council on Environmental Quality

Code of Federal Regulations

Calendar Yeár

United States Department of Energy

Lnited States Department of Transportation

Linited States Environmental Protection Agency

$A$ demineralizer systen that combines filtration with ion

exchange. This system is designed to process intemediate avel 1 iquid waste.

General Public Utibities Nu=lear Corporation

NRC Office of Inspection and Enforcement

NRC Office of Nuclear Material. Safety and Safeguards

Memorandum of Understanding

Hational Enviromental Policy Act

United States Nuclear Regulatory Commission

NRC Office of Nuclear Reactor Regulation

NRC Office of the Executive Legal Director

Programmatic Enviromental impact Statement

NRC Office a: Nuclear Regulatory Research

Reactor Coolant System

Reactor Pressure Vessel

Reactor Pressure Vessel Head

Submerged Demineralizer System, a demineralizer system that combines filtration with ion exchange. This system is designed to process high level liquid waste.

Technical Advisory and Ass istance Group

Three Mile Island Program Office

Three Mile Island Nuclear Generating Station Unit 2 


\section{THE PURPOSE AND SCOPE}

The purpose of this NRC pian is to (i) define the functional role of the NRC in cleanup operations at Three Mile Island Unit 2 to assure that agency regulatory responsibilities and objectives will be fulfilied; (2) provide a general schedule of major cleanup actions and the NRC's role in meeting these milestones; and (3) provide an update of the cleanup progress to date. The plan outlines NRS. functions in the following areas: (1) the relationship of NRC to other government agencies, the public, and the licensee for the coordination of activities, (2) the NRC review and decision-making process for the licensec's proposed cleanup activities, and (3) NRC's role in overseeing implementation of approved licensee activities.

NRC inspection functions at the site are carried out by 0 ffice of Inspection and Enforcement personnel under the direction of the onsite Thrce Mile Island Program Office and are not described in detail in this plan. 


\section{NRC FUNCTIONS}

The TMI Progran Office (TMIPO) was established within the NRC Office of Nuclear Reactor Regulation (NRR) to provide overall direction of Three Mile Island Lait 2 (TMI-2) cleanup operations. The TIIIPO has the following regulatury responsibilities.

(1) Planning and managing all NRC involvement in TMI-2 cleanup activities,

(2) Obtaining informatio: and evaluating current facility status,

(3) Analyzing and reviewing the licensee's proposed actions and procedures,

(4) Preparing technical review documents on the safety and environmental impacts of licensee-proposed cleanup actions.

(5) Approving or disapproving the licensee's proposed actions and procedures,

(6) Advising the Commission on major cleanup actions,

(7) Coordinating NRC's MNI-2. cleanup activities with other governmental agencies as necessary,

(8) Informing State and locai goverments and the public on the status and plans for cleanup activities,

(9) Overseeing day-to-day licensee activities to ensure that operations are implemented in accordance with the facility's operating license and relevant orders and plans,

(10) Ensuring activities are carried out in compliance with approved NRC 7 imits and procedures, and

(11) Cuordinating with the NRC Office of Inspection and Enforcement on its TMI -2 inspection activities.

To perform these functions, the TMIPO has establ ished a staff with management and technical expertise in key TMI-2 cleanup activities, such as radiation protection, radiological assessment, radwaste treatment, and nuclear safety. Support by experts in other disciplines is available from other NRC staff and, under arrangement with the National Laboratories. Cantractors and consultants provide teclinical assistance when the TMIPO detemines it to be necessary. The TMIPO also coordinates its activities with the 1 icensee, other Federal agencies, State and local government officials, and the public. Figure 3.1 identifies the major functions of these organizations and provides an overview of their functional relationship.

\subsection{Support Functions}

The TMIPO may request that NRC program of fices provide specialized technical support in the following areas: NRR for ecology, hydrology, 


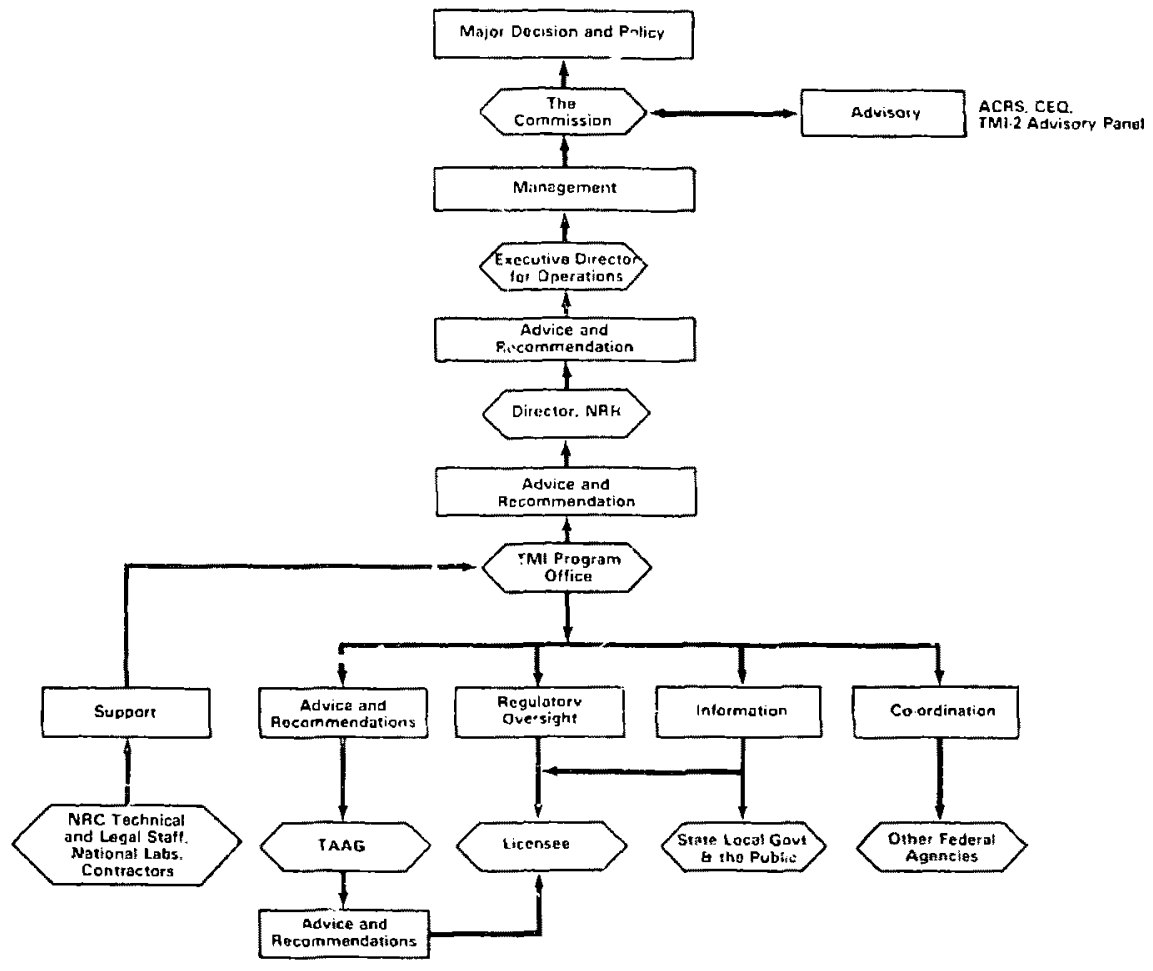

Figure 3.1 Majo: NAC Functional Roles in TMI-2 Cleanup Opezatious 
meteorology, geology, reactor core analysis, radiological assessment and instrumentation and contral systems; the Office of Nuclear Material Safety and Safeguards (MMSS) in processing, transportation, disposal and/or storage or radioactive waste; the office of the Executive Legal Director (OELO) for legal advice; the office of Inspection and Enforcement (IE) for special inspections of licensee activities; and the Office of Nuclear Regulatory Research (RES) in support for any needed research programs.

The MIIPO also obtains technical support from organizations such as National Laboratories and other contractors or consultants. These support tasks are managed by the THIPO.

\subsection{Coordination Functions}

The TMIPO coordinates NRC functions with several other Federal agencies that are participating in cleanup operations. On July 15, 1981 (revised March 15, 1982) a Memorandum of Understanding (MOU) was signed by the NRC and the Department of Energy (DDE) which formalized the working relationship between the two agencies with respect to the removal and disposition of radioactive wastes generated during the cleanup of TMI-2 (AppendiX A). The memorandum addresses the following three basic categories of TMI-2 wastes:

(1) Wastes detemined by nOE to be of generic value in terms of beneficial information to be obtained from further research and development (R\&D) activities. The MOU Calls for DOE to perform Such R\&D activities at appropriate DOE facilities.

(2) Hastes detemined to be unsuitable for commercial land disposal due to high levels of contamination, but which $D O E$ may remove, store and dispose of on a reimbursable basis from the licensee, and

(3) Low-level wastes which are to be disposnd of by the licensee in licansed, commercial iow-level burial facilities.

The MOU specifically highlights currently identified TMI-2 wastes, e.g., EPICOR-II (a demineralizer systen) wastes, Submerged Demineralizer System wastes, and reactor fuel wastes. The MOU also covers wastes which may be generated as the cleanup progresses.

The U.S. Environmental Protection Agency (EPA) is participating as the lead agency for of isite enviromental monitoring programs, and, as appropriate, the President's Council or Environental Quality (CEQ) has been advising the NRC on its National Environmental Policy Act (NEPA) responsiblities. The THIPO also coordinates with the Commonweal th of Pennsylvania, the State of Maryland, and local government officials on TMI-2 cleanup activities.

A TMI-2 technical advisory and assistance group (TAAG) has been es tablished to provide independent tecinnical assessment and advice on the decontamination and defueling of TMI-2. This group assures that approaches to the various cleanup and defueling uperations are technically adequate and that consideration has been given to maintaining radiation exposures as low as reasonably achievable (ALARA). The TAAG consists of approximately 10 pemanent members and additional ad noc members where special expertise is needed. The group responds to specific requests from any of the three parties: the licensee, the ARC-TMIPO, or DOE. 
A TMI Infonmation and Examination Program has been establisıled to acquire data which could significantly improve current understeiding of nuclear plant accident envirorments and the phenomend wirh cortribute to those environments. The licensee, the Electric Power Research Institut?, tie ARC, and the DDE, through DOE's prime r.ontractor at TMI-2, EG\&G, Idaho, Inc., jointly sponsor and participate in this program. In addition to the participation of NRC in the technical working yroup for this program, the NRC reviews the data acquisition tasks of the program to ensure that these tasks are implemented in coordination with ongoing cleanup activities, and to the maximum possible extent, utilizes these tasks and the data acquired for the benefit of the cleanup.

\subsection{Information Functions}

The TMIPO has taken on the responsibility of keeping State and local government officials and the public informed on a continuing basis of the progress and the status of cleanup operations, as well as of future plans. This function is perfomed both by the TMIPO headquarters and onsite staff and by the MIIPO Field office personnel in Middletown, PA. These of fices disseminate information (for example, the week?y plant status report on the cleanup) routinely to local officials and the public. Additionally, the staff conducts public meetings and gives interviews with the media to keep the public and locat officials informed of the status and specific aspects of tre cleanup effort.

\subsection{Advice and Recrmmendation Functions}

Licensee-proposed cleanup operations may require the approval of the Commission if the estimated environmental impacts exceed those given in the Programiat ic Enyironatental Impact Statement (PEIS). Towards this end, the TWIPO keeps the Conmission informed as to the current status of cleanup operations and planning. To facilitate Commission decision making for those proposals which require Cominission approval, the TMIPO will develop recommendations based an its review and evaluation of the licenseg's proposed cleanup plans. The TMlP0 will also infom the commission when staff actions are taken on significant cleanup activities which the staff is authorized to approve. In addition, the TMIPO providcs periodic :eports to the Commission on the status of the cleanup and future plans.

In 1980, the ARC establ ished a 12-member TMI-2 Advisory Panel to consult with and provide advice to the Commission on major activities related to the decontamination and cleanup of TM1-2. The panel consists of members from the Commonweal th of Penisylvania, local goverment, and the scientific community, as well as the public in the vicinity of TMI. The TMIPO provides liaison between the Commission and the TMI-2 Advisory Panel and also provides information. to the panel on the 5 tatus of the cleanup.

\subsection{Eequiatory Oversight Functions}

NRC maintains regulatory oversight of the licensee's cleanup activities. In general, this function is accomplished in three phases: (1) long-term planning, (2) review and approval of proposed cleanup activities prior to their implementation, and (3) gversight of day-to-day operations. The NRC maintains cognizance of the licensee's long-tem planning to assure that the licensee's 


\section{NRC REVIEH AML DECiSION-MAKING PROCEDURE}

$\because$ review and approval are required prior to the implementition of azjor cleanup operations by the licensee. Each cleanup activity proposed by the licensee sill be reviewed by the TMIPO co issire tilat all applicable :ARC requirements are met to protect the public's health and safety and rininize worker exposure. To the extent applicable, such revica will draw unon the evaluation of the cleanup aiternatives discussed in the "Prograrnitic Environmental Inpact Stateinent Related to the Decontarination and Disposal of Radioactive Wastes Resulting frombllarch 28, 1970 Ac:ident at Three Mile !sland Nuclear Plant (PEIS) (NUREG-0683) ${ }^{2}$, and any supplements to the PEIS, ; id will focus on the safety and enviromental impacts of the proposed activi-y.

In its Policy Statement ${ }^{3}$ accompanying the PEIS, the Commission directed the staff to detemine whether specific licensee cleanup proposals and the associated potential impacts fall within the scupe of those already assessed in the PEIS. If the proposed actions are within the PEIS Scope and any supplemests, the Director, TMIP0, has been delegated the approval autherity, while keeping the Cominission infonmed of the staff's actions: $:$ each major propo: 1 . If the licensee's proposal is not within the PEIS scope, the Commissiun is notified and additional reviews by the TMIP0 staff are undertaken in accordance with the Mational Environmental Policy Act (NEPA). The staff, based on an environmental and safety review, makes a recomendation on the proposed action to the Connission.

At any time, if the staff detemines that the conclusions presented in the PeIS have substantially changed, then the staff will issuc a supplement revising the PEIS in accordance with NEPA. Such a determination has been mage for the estimates of occupational radiation exposure, and a dra $[$ Supplement was issued for public comment in January 1984.

\subsection{Proposals From the Licensee}

NRC will independently reyiew the licensee's proposed actions und, consistent with NRC respon bilities, ensure that public and worker health an. safet, and the environt.ent will be adequately protected. In order to expedite the im.plementation if licensee activities, it is imperative that the 1 icensee provide timely and complete information on proposed actions to enable the MIPO staff to conduct safety and environmental reviews.

\subsection{The IRC Review Process}

The TMIPO has access to sufficient technical expertise to review, evaluate, and determine the adequacy of TMI-2 cleanup actions proposed by the 1 icensee. All such proposals wil: be reviewed by TMIP0 tc detemine whether the action can be undertaken with reasonable assurance that it will not endanger the health and safety of the public and workers and is snvironmentally acceptable. Licenseeproposed cleanup actions fall within two categories: those requiring amendments to the license and those that do not. 
(1) If the proposed action involves a request for a license amendment, the MIIPO staff first detemines if it is within the scope of the PEIS. A proposed cleanup activity is considered within the scope of the PEIS if the following conditions are satisfied:

a. It is similar to the general type of activities discussed in the PEIS for the cleanup and/or disposal of radioactive wastes from the $\mathrm{THI}$ facility.

b. Its potential environental impacts are not significantly different (qualitatively and quantitatively) from those environmental impacts assessed in the PEIS.

If the TMIPO detemines any ajor activity and its predicted environi: ita] impacts tall outsite the scope of those already assessed in the PEIS, the Commission will be infomed and the TMIP0 staff will complete necersary reviews in accordance with the NEPA and NRC requirements. If the staff deteminas that a supplement to the PEIS is appropriate, the supplemental environmental statement will be prepared under the direction of the MIPO. In the event a proposed activity falls outside of the scope of the PEIS, but does not require the preparation nf a supplemental environmental impact statement, the TMIP0 staff will publish a negative declaration to that effect and provide an Environmental Impact Appraisal in support of the negative declaration.

Figure 4.1 illustrates the NRC review process for preparing supplements to the PEIS. The public can review draft supplements to the PEI5 during a defined comment period. Other government agencies having an interest in the review, monitoring, and in some cases, participation in some phases of the proposed cleanup operation, will be involved in the review of the supplement to the PEIS. Government agencies likely to have such potential interests and their invo? vement in the review process are indicated in Figure 4.i.

In addition to any NEPA reviews, the staff will conduct a safety evaluation. The staff makes a decision regarding significant hazards. If a ignificant hazard is detenmined to exist, the pub? ic will be given an opportunity for a hearing prior to approval of the proposed action. If the staff determines that there is no significant hazard associated with the proposed amendment to the license, and if the staff recommends approva? of the action, then the amendment is issued and the opportunity for a public hearing is provided after issuance of the amendment.

(2) If the proposed action does not involve the need for a license amendment, the TMiPO first determines if the action is within the scope of the PEIS in a manner sim?lar to (1) above. If it is determined that the major activity and its predicted environmental impacts fall outs ide the scope of those already assessed in the PEIS, the Commission will be informed and the TMIPO staff will complete necessary reviews in accordance with NEPA and NRC requirements. The TMII. :11 then conduct a safety review and recormend approve? or disapproval ai ine action to the commission. 


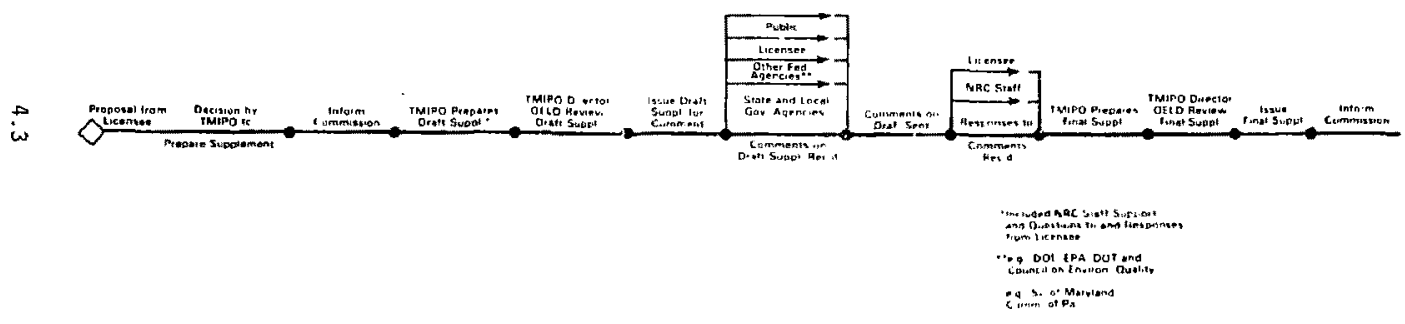

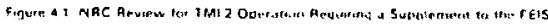


If the action is de:enmineo to be within the scope of the PEIS the stafi perfoms a safety and environmental review and infons the comission of the staff's ection on major activities propesed by tre licensee. 


\section{THE MASTER SCHEDULE OF MAJOR CLEANUP ACTIONS}

Each cleanup operation could be accomplished by a number of alternative methods. A review of generalized alternatives has been presented in the Programmatic Environmental Impact Statement. The alternative chosen for a specific operation will depend, to a large degree, on the specific condition of the facility, the anticipated environmenta? impact, end the availability of financial resources. Specific information about these conditions will become available oaly as the cleanup progresses. Depending on the alternatives selected, the type and extent of preparation and support facilities reauired will vary. For this reason, the anticipated schedule of cleanup actions will only designate the type of operation and support activities, not the methods to be used.

A1 though there are overlapping cleanup efforts (e.g., the processing of contaminated water is an on-going task). operations, in general, are expected to proceed sequentially according to the milestones slown in Figure $5 . i$. Also scheduled are a nunter of major support activities and farilities that are planned to be in plece for each milestone prior to those cleanup operations.

TaLie 5.1 outlines the master schedule of anticipated actions. Due to the present uncertainty of funding past 1984, the estimated times fur completion of various activities are presented only for Calendar Year (CY) 1984 . The present uncertainty in funding does not allow for time estimates for completion of remaining cleanup activities after $\mathrm{Cr}$ 1984. The sequence of cleanup activities, however, is anticipated to generally remain the same.

The removal of radwaste from the TMI site is an ongoing activity. With the Memorandum of Understariding between the Department of Energy (DOE) and NRC, it is expected that DOE will be able to take those radwastes needed for generic research and development and those unacceptable for commercial disposal sites. It is assumed that a commercial burial site will continue to be available for disposal of low level radioactive wastes generated throughout the cleanup. Thus, onsite stcrage of radwastes for significant periods should not be necessary. 


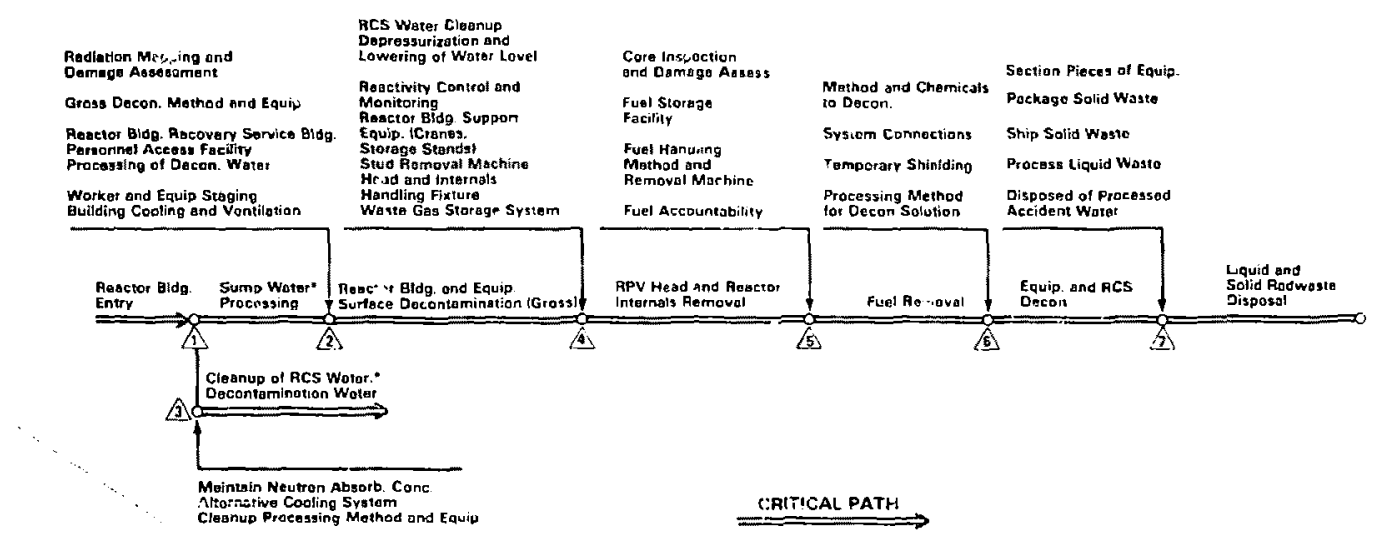

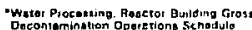

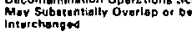

O Miles rone Priar to Docun Operatior

Figure 5.1

Critical Path and Kay Figparations for Clejnup Operations 
cleanup objectives are corsistent with those of the NRC in ma intaining the health and safety of the public and workers, and minimizing environmental impacts. Day-to-day oversight by the THIPO ons ite staff provides assurance that activities are implemented according to approved plans and assures comp'lance with existing NRC regulations, the facility's operating license, tecinical specification requirements, and approved procedures.

For certain activities, written procedures proposed by the licensee will require MIIPO review and approval. As part of the MMI-2 License, Section 6.8 of the Technical Specifications for TMI-2 details the type of activities and requirements on written procedures. (Section 6.8 is reproduced in Appendix B.) 


\section{THE NRC OBJECTIVES IN TMI-2 GLEANUP OPERATIONS}

The safe expeditious cleanup and decontamination of Three Mile Island Unit 2 (TMI-2), including removal of the fuel from the accident-damaged reactor, are necessary for the long-tem protection of public health and saf aty as well as to ensure that the TMI site does not become a long-term or permanent waste repository. The NRC is responsible for the regulation of TMI-2 cleanup operations to assure the health and safety of the public and the TMI-2 occupational workforce and the protection of the environment. For all post-accident ope rations at TMI-2, NRC has maintained the following regulatory objectives:

(a) Maintain reactor safety and control of radioactivity,

(b) Assure that environmental impacts are minimized, and that radiation exposures to workers, to the public, and to the environment are within regulatory limits and are as low as reasonably achievable, and

(c) Assure interim safe storage and/or disposal of radioactive wastes from cleanup operations.

Implementation of cleanup activities is :he responsibitity of the licensee, General Public Utilities Nuclear Corporation. However, should the licensee and its parent company go bankrupt or otherwise default on its obligation to decontaminate the TMI-2 facility, NRC's role in decontamination operations may change. Nevertheless, NRC abjectives in TMI-2 cleanup operations wili remain the same: to protect public health, safety, and the environment. The NRC staff has prepared a contingency study of NRC actions required should the licensee be unable to finance the TMI-2 cleanup, entitled "Potential Impact of Licensee Default on Cleanup of TMI-?"

(NUREG-0689). 


\section{STATUS OF CLEANUP-RELATED ACTIVITIES}

\subsection{Completed Activities}

Three Mile Island linit 2 (TMI-2) cleanup activities began soon aft: ar the accident on March 28,1979 . To date, the following tasks and associated NRC actions have been completed.

Issuance of the Final Programmatic Enviratmental impact Statement

On March 9, 1981, the Nuclear Regulatory Commission is sued a Final Programmatic Environmental Impact Statement (PEIS) (NUREG-0683) related to the decontamination and disposal of radioactive wastes resulting from the accident, In that statement, a wide range of alterratives for decontarinating the TMI-2 facility, defueling the reactor, and disposing of the radionctive wastes were considered and their potential inpacts on the environment, menbers of the public and plant worker's were indicated. In canjunction with the issuance of the PEIS, the Comitission also issued a Policy Statement in fipri 1981 which states tnat the cleanup should be expedited, consistent with maintaining publ ic health and safety. In the Policy Statement, the Cornmission also outlined the NRC's policy in the review and approval of subsequent cleanup operations.

Memorandum of Understanding with the Departiment of Energy

In July 1981, a Menorandum of Understanding (NOU) concerning the removal and disposition of abnonnal soljd wastes from the cleanup of TMI-2 was signed by representatives of NRC and the Denartment of Energy (DOE). This MOU was modified in March 1942 to include disposition of the entire damaged core. As a result af the MOU, DOE has taken the 50 EPCIOR-II first5 tage liners for research and development purposes, storage, or dicposal. Shinesui of the EPICOR-II first-stage liners to Idaho National Engineering Laboratory (INEL) began in August 1982 and was completed in July 7983 . As of January 1984 DOE has al so taken 15 Submerged Demineral izer System (SDS) liners, with shipments to DOE, Hanford, Washington.

Decontamination of the Accident-Generated s!ater in the Auxiliary and Fuel Handine Building

The decontarnination of 570,000 gallons of accidenc-generated water in the auxiliary and fuel handing building has been completed using the EPICOR-II Systen. The processing of this waste water resulted in the generation of a number of low-level waste resin liners in addition to the higher activity frefilters discussed above. In March 1981, NRC approved the shipment and disposal of commercial low-level waste consisting of 22 EPICOR-II spent resin liners used in processing this water. By July 1, 1981, all these resin liners had been shipped to the commercial waste disposal site at Hanfard, Washington, for final burial. This decontaminated water is being stored onsite and is also being used for other cleanup activities. 


\section{Krypter Venting}

Following NRC approval, the licensee purged krypton from the reactor biliding's atmosphere via a controlled purging method in June-July, 19B0. Since that time, numerous entries into the reactor building have been made by the licensee for purposes of data gathering and maintenence work in support of decontamination efforts. Very small releases of krypi, on have been made (an the order of 10 curies or less) prior to each entry.

\section{Decontamination of the Accident-Generated Water in the Reactor Building}

In September 1981, Jecontamination of the balarce of accident water located in the reactor building sump and reactor coolant system was initiated using SOS, an underwater ion-exchange system. The processing of the accident-generated water was completed in May 1982. SDS is presentiy used to periodically process reactor coolant system (RCS) water and reactor buijding sump water resulting from containment building cecontamination efforts. As of January 1984, 15 SDS vessels have been shipped to DOE, Haiford, Hashington.

Uncoupling of Leadscrews

The leadscrews to the 61 control rods and $\delta$ axial power-shaping rods have been uncoupled as a necessary prerequisite to removal of the reactor pressure vessel head.

Remote Examination Inside the Reactor Pressure Vessel

During July and August of 1983, a clused-circuit television inspection of the reactor core (termed the "Quick Look" inspection) was performed. The TV camera was lowered through the reactor pressure vessel head and upper internals at three different locations. When the camera was lowered into the core region, the observers could identify rubble approximately five feet below what was the former top of the core. Prelininary information on the radiation field under the reactor pressure vessel head was also obtained during the Quick Look examination.

During August and September 1983, a second effort was undertaken by the 1 icensee to better characterize conditions inside the reactor pressure vesse] This program was called Underhead Characterization. It included a visual inspection by remote closed circuit television camera of the plenum and the core void area. The licensee also took grab samples of the rubble bed, made a radiological examination of the area under the reactor pressure head, and conducted sonic (sonar) mapping of the core void area. Results from both Quick Look and the Underhead Characterization programs are being used to plan reactor pressure vessel head lift, plenum renoval, and defueling. 
Reaztor Builaing Polar Crane Refurbishment and Testing

The polar crane has been refurbished. The load lest procedures for the polar crane, needed for removal of the reactor pressure vossel head and plenum resliuva?, were approved by the NRC in November 1983. Load testing of the polar crane was completed in February 1984.

\subsection{Ongoing Cleanup Activities}

Some of the major ongoing activities include the following:

Supplement to the PEIS Dealing with Worker Exposure

On January 5, 1984, the NRC issued a draft Su,plement to the PEIS dealing with occupational radiation exposure. The Supplement revised upward the anticipated occupational exposure from a range of 2,000 to 8,000 person-rem, estlumated in the uiginal PEIS, to 13,000 to 46,000 person-rem. When the original PEIS was prepared, the reactor building had been entered only five times. Since then, it has been entered more than 280 times to collect data, conduct tests, perform decontamination tests and decontamination, refi..ish the polar crane, remove trash and contaminated equipment, and begin preparation for fuel removal. This increased knowiedge of actual conditions in the building, and the awareness of the penetration of contamination into surfaces and tre extent of corrosion, have resulted in higher estinates of occupational exposure.

Licensee's Dose Reduction Program

In late 1982 the licensee launched a mut timphase dose reduction progran to reduce radiation exposure to workers. This ongoing progran includes the shielding of known sources of exposure, such as floor drains, hatchas, penetrations, the enclosed stairwell and the elevator shaft. These efforts have resulted in significant reductions in the dose rate in the reactor tuilding.

\section{Reactor Building Entries}

Entries it to the reactor building for purposes of danage assessment, data collection and equipment maintenance began on July 23,1980, after the reactor building atmosphere had been purged of krypton. By the end of 1983, over 300 entries had been made by the licensee and its contractars. Prior to each entry, the NRC TMIPO ons ite staff reviews the planned tasks and radiation protection precautions and alosely monitors tlie activities of each entry. Occupational doses incurred during these reactor building entries continue to be monitored by the TMIPO staff to ensure that radiation doses are kept as low as reasonably achievable (ALARA). 
Auxiliary and Fuel Handling Building (AFHB) Decontamination

In addition to removal and processing of water Spllled in the AFHB basenent, cleanup of contaminated surfaces and equipinent in tne AFHB is about $30 \%$ conplete, with the excaption of a number of isolated cubicles. [t should be noted, however, that near-term access to these cubicles is not considered vital to reactor safety maintenar,ce or other on-going cleanup efforts in the reactor building.

\section{Plant Effluents and Waste Disposa?}

Following issuance of the final PEIs in March 1981, the technical specifications of TMI-2 governing the limits for radioactive material in effluents were amended to incorporate those proposed in Appendix $P$ of the PEIS. The technical specifications now limit the radioactive matcrial releases in gaseous and 1 iquid effluents to those stated as design objectives for operating reactors in Appendix i of 10 CF. Part 50 . Ali cleanup operations thus far have been conducted well within these limits.

Low-level solid wastes (e.g., compacted trash, dcwatered resins with radioactivity less than $1 \mathrm{u}(\mathrm{i} / \mathrm{mL}$ ) continue to be shipped to a commercial disposal site for burial.

"A ${ }^{*}$ Spent Fuel Pool Refurbishment

In September 1983 the MRC approved nadification to the "A" spent fuel pool to decommission the tank fann and refurbish the fael pool. The tank farin was utilized during SDS processing of reactor building sinp water. The refurbishment activities are designed to prepare the fuel poot for fuel removal from the TMI-2 reactor core. The licensee's activities are presently on hold pending availatility of additional funding.

Reactor Pressure Vessel Head (RPVH) 5tid Detersioning

In Sep ember 1983 the jicensee subnitted a proposal for detensioning the RPVH studs (in preparation for future head renoval) and for removal of up to five studs and associated nuts. The staff completed its review of the 1 icensee's proposal and in February 1934 provided approval in principal for this work.

Stud detensioning is nomally a routine activity during the ceactor pressure vessel head removal sequence. However, at $7 M I-2$ the studs have not been de:ensioned for a period in excess of five years and may well be stuck due to rust and corrosion of the metal surfaces. Stud detensioning is acc.mplished by relieving the tension or elongation in ear tud in two passes. The detensioning process involves stretching the studs and partidlly unwinding the nuts in a patterned sequence with a hydraulic detensioning machine. The primary purpose of stud detensioning is to check for stuck nuts and studs so that tooling and procedures can be developed to facilitate future head removal. 
Renoval of the studs and nuts will penit exanination of their condition and provide information necessary for their safe handling and subsequent packaying and disposition. The licensee plans :o begin detensioning in nid $-? 984$.

\section{J Future Activities Requiring NRC Review ar,d Approval}

\section{Building and Equipment Surface Decontamination}

The purpose of this cleanup activity is to decrease the radiation fiald within the reactor bullding so that occupancy-intensive activities, such as hands-on decontanination work related to fuel removal, can be carried out.

Cleanup of he reactor building and equipment will result in an estinated 5,900 to 21,000 person-rem of cccupational radiation dose. As much as $30 \%$ of this dose is associated with cleanup of the reactor building bäjement.

Final cleanup of cubicles and systems in the AFHQ, including the processing of decontamination waste from system and tank cleanup, is estimated to require be tween 500 and 1,400 person-rem. Licensee plans for some of these efforts have recently been approved by the TMIPO.

TMIPO approval of future decontamination proposals will be based an a review of:

1) radiation levels from reactor building radiological surveys,

2) methods for gioss and subsequent manual decontamination that specifies equipment and procedures needed for cle nup operations,

3) methods for processing the resuiting decontamination liquids and packaging and storing the resultatt radioactive wastes,

4) the interaction of the proposal and the dose reduction program,

5) proposed final conditions for areas to be dccoritaminated, including pläns for final surveys, and

6) the safety and envirormental consequences of the proposed action.

The draft Supplement to the PEIS dealing with occupational radiological exposure determined that decontamination of the reactor bullding would be the single most significant contributor to the total occupational exposure during cleanup of TMI-2. Consequently, the NRC staff will closely monitor this decontamination effort and monitor occupational exposures incurred to ensure adherence to the ALARA principal. 


\section{Reactor Pressure Vessel (RPV) Head and Reactor Unfer Internals Removal}

The 1 icensee's proposal for these activities will be based on prelift examination data and should contain information on methols of RPV head and reactor upper glenum as sembiy removal. Special consderation will be given to damage fron the accident that could possibly hinder removing the RPV head le.g. dis. tortion, warping, and/or physical dislocation), criticality control, core cooling, reactor coolant cleanup, RCS dapressurization and lowering of reactor coolant level. The following itens will also be reviewed by the staff regarding these proposed activities:

(1) the radiation levels expected in the worker occupancy areas,

(2) total occupational exposure and radiation protection features,

(3) Safety concerns of equipment handing to prevent heavy loads from striking the core after RPV hear removal,

(4) airborne radioactivity control and elivironmental consequences, and

(5) detailed procedures for accompl ishing this work.

Other support systems, facilities, and equipment requiring NRC reviews include systems to monitor and control the reactivity of core deuris, a system for the processing and storage of waste gases from the primary cooling systein, facilities for the staging and storage of the RPV head and internals, an RPV head and internals handling fixture, and stud-removal equipment.

\section{Fuel Removal}

The licensee's propasal should contain information on the status of the reactor following the RCS water cleanun and RPV head and reactor upper plenum removal operations, with special attention given to those factors that would affect core examination (e.g. , reactor water purity, fuel assembly dehris, zist radi?tion leveis at the top of the RPV). The staf $f$ review would also incluce the following items with regard to fuel removal activity:

(1) the proposed core examination objectives and methods;

(2) condition of the core and methods to prevent recriticality during defuel ing operations;

(3) fuel removal methods (including the anticipated condition of the damaged reactor core and proposed procedures to remove the fuel under those conditions);

(4) methods to retrieve and remove materials that may become detached (e.g., fuel pellets, cladding fragments; during the proposed fuel removai; 
(5) methods of fuel transfer, canning, and storage;

(6) fission product monitering and potential for releaces;

(7) the safety and environmental consequences of the proposed action, including estimates of occupational exposures and radiation-protection meas:aces requi:ed to maintain these doses MLARA;

(8) an analysis of the potential consequences of a drooped fuei assembly andior an accident caused by equipment dropped onto the reactor care:

(9) the design criteria and technical infomation about the zquipment proposed for tire core exariatiotion and fuel remova? operations, and

(10) detalled procedures for each phase of the defueling operation.

A number of support systems and special equipment for the proposed actions wi? I require ARC review. Thase itens include equipment for core exenination; fuel containers and a storage facility; underwater $\mathrm{Cl}^{*}$ ing and grappling equipment; fuel handling and lifting apparatus; a fission-product gas monitoring and processing system; detached material collection al 1 cleanup systems and a water cleanup system. In addition, during this phase of the cicanup operation, the NRC stafi will be ir. close coordination with DDF.

Reactor Coolant System (P.CS) Decontamination

The licensee's proposal for tlis operation shouid contain informetion on the levels of conta:ination of, and damage to, the reactor system components that require decontanination or renoval. For each of these majcr components, clcanup methods should be proposed (e.g., drain/flush and chemical decontamination and/or renoval). The staff review of the proposal will al:a include considiration of the following topics:

(1) the anounts, activity levels, and chemical properties of 1 iquid radwastes to be generated from the nrnoosed action,

(2) the inethods of detexting fuel and fission prudicts,

(3) the method for processing the liquid radwaste ind the expected results.

(4) radiation piotection features and estimates of ociupational exposures,

(5) criteria and information for RCS decontamination, and

(6) detailed procedures proposed for the operation. 
Depending on the condition of the facility and on the proposed method of cleanup, supporting systems for this operation may include the use of the reactor coolant pumps, soecial equipment for high-pressure flushing of coolant lines, systems to prepare and introduce chemical decontarination solutions, sol id radwaste processing systems, and processed decontamination water and solid radwaste starage or staging facilities.

Purification Demineralizer Removal

The licensee has committed to the NRC staff that the contents of both g0-cu.-ft. RCS resin demineralizers will be prepared for disposal by the end of 1984. These demineralizers were loaded wi il s ignificant quantities of fission products (i.e., cesium-137 and strontium-90) and fuel debris during the March 1979 accident. Data is currently being collected to better detemine the optimum processing and disposal technique. Preliminary plans for processing will involve a cesium-removal phase and a resin cluicing phase. The licensee will be submitting Safety Evaluation Reports for staff review and approval, for both phases of activities. The cesium-removal phase is scheduled for the fall of 1984 and resin sluicing by the end of the year. 


\section{LICENSEE IHPLEMENTATION DF ACTIONS}

The licensec is responsible for maintaining reactor safety and for implementing NRC-appraved actions throughout the Three Mile Islant Unit 2 (TMI-2) cleanup operation. NRC's responsibility is to ensure that the licensee's actions meet NRC cleanup objectives and that they are implemented according to existing regulations, TMI-2 Operating License and technical specifications, and approved procedures. The NRC is also responsible during the implenentation of cleanuF actions for coordination with other agencies involved in the cieanup.

\subsection{NRC Actions}

The ARC, mainly through the onsite THIPO, will maintain cognizance of the current status of on-going cleanup operations to ensure that they are proceeding according to NRC orders, the facility operating license and technical specifications, and approved procedures.- The licensee's monitoring data and effluent release reports will be reviewed. independent monitoring of 1 icensee results will be perfomed. This information and the progress of cleanup operations will be routinely communicated to government officials and the public, for example, through the issuance of weekly plant status reports.

\subsection{0ther-Agency Actions}

Other agencies will participate in cleanup operations. For example, the Environmental Protection Agency (EPA) has the responsibility to mollitor the area around Three Mile Island. The Department of Energy (DOE) has proposed a major research and development and data acquisition program in connection with the cleanup to ensure that useful generic infomation is obtained and disseminated. Pursuant to the July 15, 1981 (revised March 15, 1982) Menorandum of Understanding with IRRC, DOE has, as part of its program, agreed to accept radioactive wastes for research and development purposes. Also, the TMIPO will continue to be in contact with the Pennsylvania Department of Environmental Resources and the Maryland Department of Natural Resources. These and any other activities that may be needed from Federal, State, or local government agencies will be coordinated by the TMIPO.

ॠSee Section 3.5 for procedures requiring approval. 
8 REFERENCES

(1) NUPEG-0698, "Potential Impact of Licensee Default on Cleanup of TMI-2," Novenber 1980.

(2) NUREG-0683, "Final Programmatic Environmental Impact. Statement Related to Decontamination and Disposal of Radioactive Hastes Resulting From March 28, 1979, Accident Three Mile Island Nuclear Station, Uní 2 ," March 2, 1981 .

(3) NRC Policy Siatement on Cleanup of Three Mile Island Plant, April 28, 1981 .

(4) NUREG-0683, Supp. 1, "Programatic Environmental Impact Statement Related to Decontamination and Disposal of Radioactive Hastes Resulting from March 28, 1979, Accident Three Mile Island Nuclear Station Unit 2, Oraft Supplement Dealing with Occupational Radiation Dose," December 1983. 
Appendix A

Menorandum of Understanding

Between the

U.S. Muclear Regulatory Cotinission

and the

U.S. Departwent of Energy

Concerning the Removal and Disposftion of Solld Nuclear Hastes

from Cleanup of the Three Hile Island Unt 2 Nuclear Plant

\section{Objectfve}

This menorandum of undarstanding specifles interagenc $/$ procedures for the removal and disposition of nuciear wastes resulting from cleanup of the Three Mile island Unit 2 plant. This will help to ensure that the TMI Site does not become a long-term waste isposal facility.

II. MRC Roles and Responsibilities

The NRC has the responsibility under the Atomic Energy Act of 1954 as amended (42 U.S.C. 2017 et seq.), to regulate all licensee activities at the THI-2 site, including wast management, and ensure these activities are carried out in accordance with the reouirements of applicable rules and regulations and the requirements of Facility Operating License lumber DPR-73, as modiffed by amendments or orders issued by the NRC. NRC wili carry out its responsibilities by onsite observation of licensee activities. As required, policy, and technical support will be provided to the NRC TMI Site office by NRC headquarters and Regional office(s).

NRC wil work couperatively and closely with the DDE, and will keep DuE fully and currently informet of NRC's activities.

NRC will continue to keep public, state and local officials infomed of NRC's activictes When appropriate, NRC will involve DOE in these information exchanges with the public, scate and local officials. 
III. DOE Role and Responsibilities

Where DOE deternines that generically beneffcial research, development and testing of the TMI-2 accident generated solid wastes can be carried out, one will perform such activities at appropriate DoE facllities. For those other wastes that cannot be disposed of in cominercial low level waste facilities, DOE may also assume responsibilify for removai, storage, and disposal to the extent that the licensee provides reimbursement to the DOE. These activities w111 be undertaken to the extent consistent with appropriate statutory authority. NRC 11censing of DOE facflities that are utflized for storage, processing or disposal of TMI-2 accident generated wastes will not be required since these factifties have primary uses other than for receipt and storage of wastes resulting from licensed activities.

The DOE will provide technical support to the licensee and the NRC as detmed appropriatt.

DOE will work r'osely with the NRC and keep NRC informed of DOE's activities.

IV. Currently Identified TMI-2 Accident Generated Solid Radioactive Wastes The following lises those MII-2 accident generated solid radioactive wastes which currently exist or are planned to be generated. This listing may be modified in the future as the cleanup progresses. 


\section{EPICOR-II System Hastes}

Forty-nine fon exchange resin liners with loadings up to 1500 curfes/liner are in temporary starage at the TMI-2 stte. DOE plans to develop a prototype high integrity container (HIC), production unt ts of which, if utflized by the licensee, may aliow these liners to be acceptable for licensed disposal in comerstal land burial facllities some $1-2$ years from now. DOE is also performing characterization experiments on one of these liners and may find it desirable to extend its R\&D program to ather liners. Should a mor: expeditious handiing of these wastes be required due to the potential for a $11 m i$ ted release to the storage environnent (which cauld cause pubilc concern), a contingency plan will be implemented wherein DOE would at its discretion take recefpt of these EPICOR Iiners on a reimbursable basis from the itcensee for storage or disposal. Future PICOR-II In ners are anticipated to be loaded to allow conmercial shallow land disposal offsite by the licensee.

\section{Submerged Demineralizer System Wastes}

It is antiefpated that the dispersed radiodctivity in accident generatef :ater will be deposited on zeolites in submerged denineralizer system (SDS) liners. Due to the unique character and nature of these wastes, DOE will take possession of and retain these liners to conduct a waste imtiobilization research and development and testing program. 


\section{Reactor Fue?}

Following renoval of the damaged core from the reactor vessel, the entire core will be shipped to a DOE factlity to survey and seiect those portions most appropriate for DOE's R\&D program. information obtained from detafled examinations is expected to be of generic benefit to design, fabrication arid operation of reactor cores in a safe and efficient manner for current and future nuclear power plants. The realainder of the core will remain in storage at the DGE factilty and will be uitimately disposed of under an agreement to be neçotiated between DOE and the owner.

4. Transuranic Contaminated Waste Materiais

As the cl sanup progresses, sone waste materials (e.g., sludges) mary be found to be contaminated with transuranics at levels above which commercial low level burial facilities are authorized to accept. Alternatives for such material will be considered on a case-by-case basis and could include archiving, izo evaluation or temporary storage onsite, or at a DOE facility awaiting further processing and/or disposal in a pemanent repository offsite. Depending on the nature of these materials, DOE's activities could either take the form of an R\&D progran of generic value, or would be subject to reimburstrint by the licensee.

5. Makeup and Purification System Resins and Fllters During the TMl-2 accident, the makeup and purification system demineralizer vessels and filters were highly contaminated by letdown 
of reactor coslant through the system. These resins and filters have not been charactarized, however, based on radfation measurements, the resins and filters are belfeved to have specific activities well in excess of the loadings on the high specific activity EPICOR-II prefilters and are considered unsultable for commerclal land disposal. Due to the generic value of the informatien to be obtained and the very high spectfic activities of the filters, DOE wili take possession and retain these filters for researct and development activities. DOE will also take possesston of and retain purification system restins elther for an R\&D program of generic value or for storage or disposal on a reimbursable basts.

\section{Other Solld Radloactive Hastes}

The low-level wastes assoclated with decontaninatfon (e.g., some ion exchenge medta, booties, gloves, trash) will be disposed of by the licensee in licensed comercial low level burial facilities.

V. This Memorandum of Understandfing will take effect when it has been signed by the authorized representative Indicated below for each agency. UOE and ARC shall each have the right with the consent of the other party to modify this agreement.

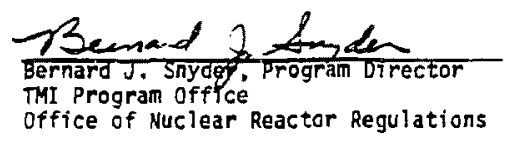

Date: $3 / 15 / 82$

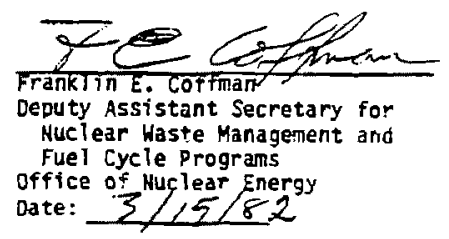


MI-2 Technical Specification on Written Procedures

\subsection{PROCEDURES}

6.8.1 Written procedures shall be established, implemented and ma intained covering the activities referenced belaw:

a. The applicable procedures recommended in Af "sndix "A" of Regulatory Guide 1.33, Revision 2, February 1978.

b. Recovery Operations Plan implenentation.

c. Surveillance and test activities of safety-related equipment and radioactive waste management equipment.

d. Security Plan implementation.

e. Emergency Plan implementation.

f. Radiation Protection Plan implementation.

9. Limiting the amount of overtime worked by plant staff members performing safety-related functions ir accoruance with the NRC policy statement on working hours as transinitted by Generic Letter 32-12.

6.8.2.1 Each procedure and any change to any procedure prepared pursuant to 6.8.1, shall be preparat, reviewed and approved in accordance with 6.5 and will be reviewed periodically as required by ANSI 18.7 - 1976.

\subsubsection{Procedures of 6.B.1.a and changes thereto which:}

a. Directly relate to core cosling, or

b. Could cause the magnitude of radiological releases to exceed 1 inits established by the NRC, or

c. Cauld increase the likelihood of failures in systems important to nuclear safety and radioactive waste processing or storage, or

d. Alter the distribution or processing of significant quantities of stared radioactivity or radioactivity being released through !nawn flow paths.

Shall be subject to approval by the NRC prior to implementation.

6.3.3.1 Temporary changes to procedures of 6.8 .1 may be made provided if:

a. The intent of the ariginal proccdure control is not altered, and 
TABLE 5.1

TMI-2 ESTIMATED COMPLETION DATES

OF SCHEDULED MILESTONES

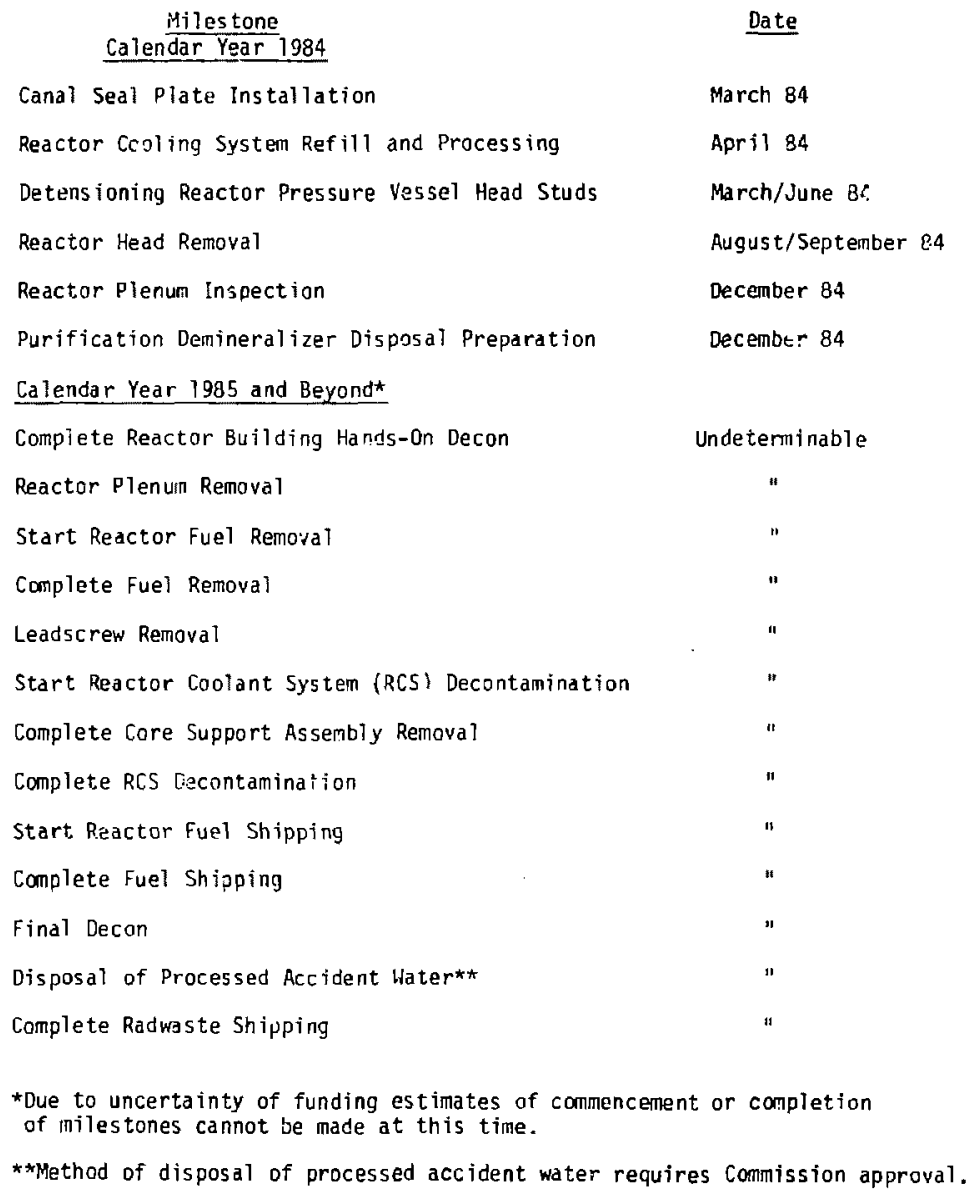




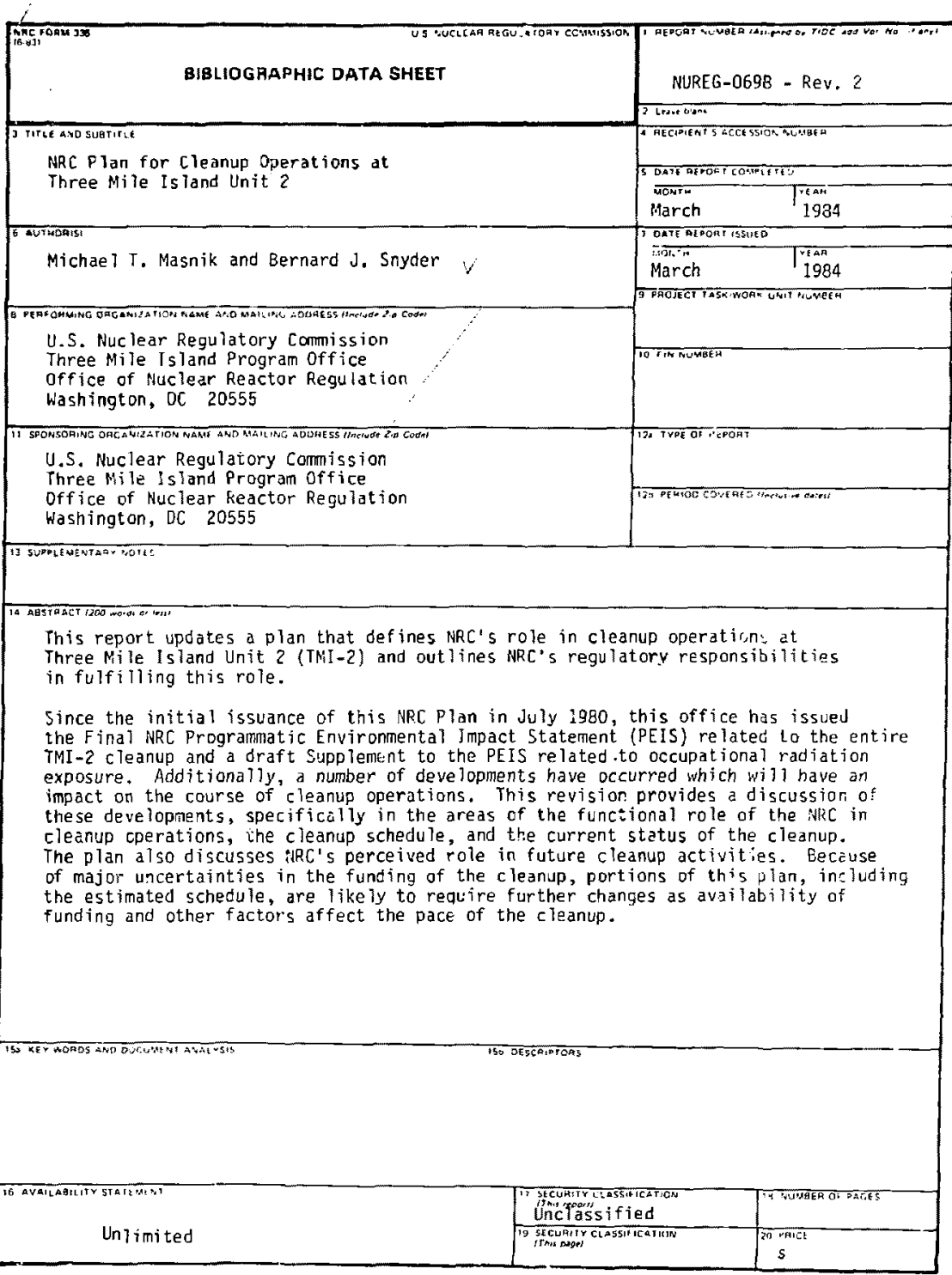

